\title{
Symbolic Geographies and the Politics of Hungarian Identity in the 'Populist-Urbanist Debate,' 1925-44
}

\author{
Richard S. Esbenshade
}

\begin{abstract}
This article examines intellectuals' debates about national identity in interwar and World War II Hungary to uncover their connection to underlying "symbolic geographies" and "mental maps." Focusing on the way in which Hungarian identity and history have been informed by, and indeed inserted into, virtual spatial rubrics that rely on the historically developed cultural concepts of "Europe" and "Asia," and "West" and "East," the paper looks in particular at the "populist-urbanist debate" that raged between two groups of writers, both opposed to the ruling neo-feudal order. The populists were composed mostly of provincial-born intellectuals who saw the recognition and uplift of the peasant as the key to Hungary's salvation. The urbanists were cosmopolitan intellectuals, mostly of assimilated Jewish origin, who saw the wholesale adoption of progressive Western rights and norms as the only way forward. Geographical characterizations of self and other became powerful tools in these groups' contestation for cultural authority and the right to lead Hungarian society. These debates both drew in - and were themselves impacted by - other actors, such as writers in government-affiliated journals, the "raceprotection movement," and the extreme right, producing a political field created in a multivalent dialogue. Despite tendencies on all sides to essentialize these geo-cultural binaries, this study argues that these struggles ultimately constituted a productive engagement with problems of Hungarian identity.
\end{abstract}

Keywords: Symbolic Geography, Populist-Urbanist Debate, National Identity, Hungarian History, Intellectuals

Biography: Richard S. Esbenshade is currently Research Associate with the Russian, East European and Eurasian Center at the University of Illinois, Urbana-Champaign. He previously taught East European, European, and World History in the History department there, including a course entitled "Nation and the Geographical Imagination." He is also a free-lance writer and translator. His involvement with Hungarian history and politics began with his first visits to Hungary in the mid-1980s. Since getting married in Budapest in 1988, he has spent at least a month or two there every year, with several longer residences. This article draws on his Ph.D dissertation, The Divided Construction of Hungarian National Identity in the Populist-Urbanist Debate, 1929-1944 completed in 2006. 
Esbenshade, Richard S. "Symbolic Geographies and the Politics of Hungarian Identity in the 'Populist-Urbanist Debate,' 1925-44." Hungarian Cultural Studies. e-Journal of the American Hungarian Educators Association, Volume 7 (2014): http://ahea.pitt.edu DOI: 10.5195/ahea.2014.174

At the legendary August, 1943 Balatonszárszó gathering of populist writers and young intellectuals attempting to chart an alternative future course for the nation, populist iconoclast and ideologue László Németh (1993 [1943]: 51-52), when asked to explain his key concept of the harmadik oldal ['third way'], his ideal for Hungary, famously stated: "Let's say that in New Guinea there's a party that supports New Guinea belonging to the English. Another believes that New Guinea can prosper only under the Dutch. And now someone stands up and asks: Can't New Guinea belong to the Papuans? That's the third way" [Tegyük fel, hogy van Új-Guineában egy párt, amely azt vallja, hogy Új-Guineának az angolokénak kell lennie. A másik szerint ÚjGuinea csak a hollandok alatt lehet boldog. S most föláll valaki, és azt kérdi: Nem lehetne ÚjGuinea a pápuáké? Ez a-harmadik oldal]. At first glance, this seems an astounding statement; what connection could there possibly be between a southeast Asian island tribal people and one ensconced for over a thousand years in the heart of Europe? And who would be questioning Magyar sovereignty in the country they ethnically dominated after the 1920 Trianon peace settlement? But Németh's statement was part of over a decade of jousting between critical intellectuals for cultural leadership, in which often fantastic-seeming geographical references were prominent. Hungarians' centuries-long insecurities about their degree of belonging to Europe, coupled with their historical Central Asian ethnic origins and linguistic isolation, gave a particular grounding and force to geographical or quasi-geographical signifiers such as "West" and "East," "Europe" and "Asia," which had been part and parcel of intellectual self-examination since at least the early $19^{\text {th }}$ century.

In this article, I will use aspects of the "populist-urbanist debate" in interwar and wartime Hungary to examine how symbolic geographies and "mental maps" were employed in intellectuals' struggles for legitimacy, cultural capital, and the right to represent the nation. The populist writers were provincial-born intellectuals who engaged in a struggle for radical land reform, education, and uplift of the impoverished rural masses, and recognition of the peasant as the essence of national life and culture. They saw Hungary as destined for its own unique historical path, while constantly subject to larger forces or powers which restricted it. The urbanists, who were cosmopolitan, mostly of Jewish origin, and unabashedly Western-oriented, were also passionately engaged in an attempt to reform the nation, but in a legalistic manner, emphasizing formal aspects of democracy, civility, and free expression. They saw Hungary as firmly bound to the Western/European model. The deep-seated cultural conflict between these two oppositional groupings has been cited as the root of a continuing division in Hungarian identity and world-view, which invokes not only rural-urban opposition but also divergent attitudes towards the West and the elusive idea of Europe. While their publishing and organizational activities involved real factors of "place" and "space," most striking is the situation of their discourses in the virtual space created by generations of their predecessors wrestling with Hungarians' place in Europe and the world, and their resolute wielding of virtual geographical concepts as weapons in this struggle.

\section{The Geographies of Hungarian History}

The Magyars' historical experience has produced an inherently complicated relationship to Europe and the West. It includes migration from the Central Asian steppe and rapid adoption of Western Christianity (albeit enforced "by fire and sword") and the defense of Europe against invading hordes (Mongol and Turk) from the East, and subsequent subjection to domination by Western powers. Beyond these much-mythified ethnic origins, the Magyar tongue is completely unrelated to any of its neighbors, and despite centuries of borrowings from its Slav, Turkic, 
Esbenshade, Richard S. "Symbolic Geographies and the Politics of Hungarian Identity in the 'Populist-Urbanist Debate,' 1925-44." Hungarian Cultural Studies. e-Journal of the American Hungarian Educators Association, Volume 7 (2014): http://ahea.pitt.edu DOI: 10.5195/ahea.2014.174

Germanic, and Latin neighbors, is very much an "orphan" from a linguistic point of view. In addition, Hungary shares the ambiguities of East-Central European development: nobilitydominated politics; agriculture-based economy and traditions; limited bourgeois development carried out largely by "non-native" groups (Jews and ethnic Germans); and a difficult history of coexistence with the myriad ethnic and national groups in the region. Thus there are ample justifications available for rejecting the West and its implied prescriptions for successful nationhood and progress. At the same time, there is the history of eager adoption of principal aspects of Western (European) culture and thought, from King István through the Renaissance, Reformation, Enlightenment, and Romanticism, leaving both a longing for promised benefits and a feeling of unrequited affection, if not outright betrayal (Janos 1982, 2000).

This history has produced constant debates, both coded and overt, about Hungary's (symbolic) location, as "Western," "Eastern," or something in between (Gal 1991). Within these debates are embedded questions of development, cultural politics, economic policy, political power and, ultimately, who will lead the nation forward. Working one's way through the debates on these or other topics, one cannot avoid symbolically loaded geographical epithets flying thickly through the discursive space, from references by urbanists to the "azsiai" ['Asian'] character of the Hungarian Plain and its inhabitants (B. Zsolt 1992 [1939]: 37) to populists' charges that urbanist intellectuals were more familiar with Paris cafes or even the French countryside than with Hungarian villages an hour's ride from Budapest, getting to know which would be "nehezebb vállalkozás, mint egy fölfedezö utazás Középafrikába" ['a more difficult enterprise than an expedition to Central Africa'] (Illyés 1933a: 341-42).

After World War I, geography turned vital for Hungarians (see Gyuris and Hajdú in this issue). The imposed 1920 Trianon treaty and the nation's "dismemberment" became imprinted on the national map, in both its "lost" and truncated versions. This truncated reality (and the underlying fantasy of regaining the territories) was then drilled into every schoolchild's head through the interwar period. The ubiquitous mantra Kis Magyarország-nem ország; nagy Magyarorszag—mennyország! ['Small Hungary—not a country; Big Hungary—heaven!'], for example, accompanied dramatically rendered maps on the wall of every classroom showing rump Hungary surrounded by the removed pieces (see Hanebrink 2006, Zeidler 2007, and Jobbitt 2011). With official revanchism serving as the Horthy regime's chief legitimation and point of contact with its subjects during the interwar period, even oppositional intellectuals were hardpressed to remove themselves from territorial or geographical thinking. Paraphrasing Robert Darnton (1994), "thinking with" geography became natural.

Hungary's integration into the ruling cultural system of Western Christianity soon after the Magyars' arrival in what later came to be considered "European space" made a European identification, for good or ill, an unavoidable starting point for those thinking about Hungarian identity in the early twentieth century. The battles between Hungarian forces and invading Ottomans from the early sixteenth century onwards cemented Hungary's (self-)identity as "Europe's defense bastion," defending (ungrateful) Christian Europe against the Moslem hordes. This military conflict, active over almost 200 years - and felt as a threat for several centuries thereafter - conditioned another key component of Hungarian identity: namely, the nation as a "borderland" (McNeill 1964; Kürti 2001). Thus it was perhaps inevitable that this real borderland aspect would be incorporated into the Hungarian cultural imagination. Most famously, Endre Ady envisioned a "kompország" ['ferry country'] eternally traveling between East and West (Ady 1905). By the interwar period, largely as a function of the political and cultural conflicts that led to the populist-urbanist divide, the "hybrid identity" represented by 
Esbenshade, Richard S. "Symbolic Geographies and the Politics of Hungarian Identity in the 'Populist-Urbanist Debate,' 1925-44." Hungarian Cultural Studies. e-Journal of the American Hungarian Educators Association, Volume 7 (2014): http://ahea.pitt.edu DOI: 10.5195/ahea.2014.174

Ady had largely split. Diehard Europhile urbanists faced off with fantasists of the fajvédö mozgalom ['race-protection movement'] — which several key populists were involved with or sympathized with, though others criticized and ridiculed it—who pressed the Magyars' "Asian" character. ${ }^{1}$ Still, as one article title put it, many commentators, especially on the populist side, located Hungarian identity as "kelet és nyugat között" ['between East and West'] (Keresztury 1934).

Another salient category or location for Hungary and Hungarian identity is "Eastern Europe." This identifier is of course much more cultural and normative than it is geographical, in a physical or "real" sense. Though the Cold War creation of the Eastern Europe we have come to know was still in the future during this period, Larry Wolff (1994) has shown how the category's oppressive "Othering" effects were solidly established during the Enlightenment. While the interwar urbanists did all they could to drag the country towards Western Europe, populist and allied intellectuals were more interested in giving Eastern Europe a positive valence, as a source of commonality and solidarity. This orientation appeared already in 1925 in the Miklós Bartha Society (Bartha Miklós Társaság, or BMT) youth movement, a key incubator of the populist idea, one of whose lecture series directly addressed the country's role in the region, producing such declarations as "Magyarország kelet-európai hivatása" ['Hungary's East European calling'], in which were proposed a "keleteuropai (orientális) kulturai únio" ['East European (Oriental) Cultural Union'] (Csebi Pogány 1929). The idea played both on the shared "peasant nature" of the surrounding societies, and on their common character as "small states" stuck between - and, inevitably, at the mercy of - two great powers, Germany and Russia.

Thus Hungarians, in thinking about their national identity, have long been and continue to be buffeted by various and conflicting currents involving and surrounding the ideas of "Europe," "Asia," "West" and "East," all strengthened in the interwar period by the intense concern with the location of the nation spawned by Trianon. But how does the recognition and exploration of this "geographical" aspect of thought and discourse help to explain and analyze intellectuals and their products? How can we use geography to "think with"? Franco Moretti, in his landmark sketch of the possibilities of using geography as a lens for studying nineteenth century European literature, states that "geography is not an inert container, is not a box where cultural history 'happens,' but an active force, that pervades the literary field and shapes it in depth" (Moretti 1998: 3). Moretti uses Benedict Anderson to wonder how (and, most pointedly, where) one sees the nation-state (16-17). Anderson (1991) and his disciple Thongchai Winichakul (1994) describe the modernization of the "geographical discourse," from realms constituted spiritually to the national space fixed on maps. ${ }^{2}$

\footnotetext{
${ }^{1}$ This effort reached a political and necessary geographical endpoint with the wartime assertion of an ethnic link to Japan (Okolicsányi 1942).

${ }^{2}$ Though such a shift was long completed for the empire as a whole through the bureaucratic and military evolution of the Habsburg monarchy, I would argue that, for Hungarians, Trianon was key for moving the national (imagined) geography from the old (dynastic) era to the modern one of geopolitics and conflict: Hungarians had continued to think in terms of the "historic Hungary" founded by King István, which had not in fact existed for almost 400 years, but which the 1867 Ausgleich had given them putative dominion over.
} 
Esbenshade, Richard S. "Symbolic Geographies and the Politics of Hungarian Identity in the 'Populist-Urbanist Debate,' 1925-44." Hungarian Cultural Studies. e-Journal of the American Hungarian Educators Association, Volume 7 (2014): http://ahea.pitt.edu DOI: 10.5195/ahea.2014.174

What I am after here is something different, though it certainly presupposes that crucial process. The map of the nation, after being fixed (if still contested) geographically, is superceded or (re-)abstracted, to be further contested in a consciousness informed by and even grounded in that modernization process, but leaping beyond it to the symbolic realm. While Moretti plots out imaginative processes on real maps, I will attempt to examine essentially political processes as plotted on virtual maps. ${ }^{3}$ This is not Anderson and Winichakul's modernization process, but a "postmodernization" of geographical discourse, in which location becomes shifting and relative.

There is of course also the very real and physical aspect of space. A process of mapping, as Moretti shows so well, means taking space seriously. While I will by and large focus on the realm of the discursive and virtual, the question of the relation between physical and mental space, or between the "objective" and "subjective" aspects of intellectual geography, requires some reference to physical itineraries. For example, populists like Gyula Illyés were of provincial origins, and used education to make their way to the capital, and ultimately to Paris and other points West. They ultimately began to disparage Budapest and its role in Hungarian culture, while maintaining a necessary residence in the city, to deal with journals and publishing houses practically all located there, but keeping one foot in the village by way of a part-time country residence. Urbanists like Bertalan Hatvany were, on the other hand, born in and bred by the "city air" of Budapest. Travel invariably took them to other European capitals, but they were at home in the hyper-urban coffee-house milieu of a very few quarters and even blocks of Pest. Béla Zsolt - who in fact was born in the Transylvanian town of Nagyvárad (today Oradea, Romania) - was notorious for the almost parodic extension of this, spending his days and nights within a couple of blocks of the Pest square Oktogon, unfailingly traversing the distances from his hotel residence to his regular cafè, and from one cafè to another, by taxi. ${ }^{4}$

The question of Space inevitably raises the question of Time: the relation between geography and "Progress," or between (symbolic) location and the perceived speed of history. Maria Todorova, in an article on temporality and the evaluation of nationalism in the Balkans, has done a parallel exploration to the kind of critical approach to symbolic geography I am looking for (Todorova 2005; see also Esbenshade 1997). Nationalism, like other phenomena or institutions, in the dominant historiography is said to have developed historically "late" in semior non-Western entities (such as "the Balkans" or "Eastern Europe"), and thus to be merely derivative of the core "Western" standard. An oppressive perception of different temporalities or time-scales is joined to a spatial or geographic judgment, branding these entities "backwards" or, at best, "catching up." Todorova also addresses the anthropological attitude typically employed in analyzing the non-West (including Eastern Europe), which is invariably distanced in terms of

\footnotetext{
${ }^{3}$ Though Moretti's project is clearly different from mine—seeing "maps not as metaphors, and even less as ornaments of discourse, but as analytical tools"- he does speak of a "mythic geography" in nineteenth-century (especially English) literature, of colonies that rarely appear as a setting, but rather function to remove the production of wealth — and, when necessary, characters - away from the local (class) context (Moretti 1998: 3, 27).

${ }^{4}$ Ferenc Fejtö, another key urbanist, was actually born in Zagreb, and Attila József, who was a kind of crossover figure, grew up in a small village. The populist Péter Veres managed to live full-time in the countryside (in Balmazújváros). So clear generalized patterns break down somewhat in individual cases, but I do not see this as a reason to avoid scrutinizing the issue.
} 
Esbenshade, Richard S. "Symbolic Geographies and the Politics of Hungarian Identity in the 'Populist-Urbanist Debate,' 1925-44." Hungarian Cultural Studies. e-Journal of the American Hungarian Educators Association, Volume 7 (2014): http://ahea.pitt.edu DOI: 10.5195/ahea.2014.174

both Time and Space from "normal, civilized" life. Zsolt’s description of the Hortobágy puszta ['steppe'] exhibits this intertwinedness in referring to the land as "biblical," "medieval" and "early Christian" in between the repeated designation "Asian" (an ironic juxtaposition most likely unrecognized by him) (B. Zsolt 1992 [1939]: 38). Moretti, noting that the journey from countryside to capital in nineteenth century British literature is habitually figured as one from youth to age (Moretti 1998: 65), provides another relevant example of what I might call "symbolic chronography." This evokes the repeated populist descriptions of villages in the grip of egyke - the trend of one-child families, primarily due to land pressures - as "old" (full of old people, without children, silent, dying), and figuring the journey from the capital to the village as one from "youth" (boisterous, growing) to "age." The aspired-to ideal of youth represented by the BMT, for example, (as in its notable pamphlet Ifjú szívekben élek ['I Live in Young Hearts'] (n.a. 1928)) and also by János Böjthe, the young, vigorous, uncorrupted hero of populist progenitor Dezső Szabó's seminal Az elsordort falu ['Swept-Away Village'] (D. Szabó 1989 [1919]) is thus reversed.

A more particular, and crucial, aspect of the symbolic geography of both populists and urbanists, and in fact of all Hungarians in this period, is the issue of Germany and Germanness, which loomed large in the consciousness of Hungarians in many different, and often contradictory, ways. For the urbanists, Germany represented a major fount of culture and Bildung, especially in the persons of Goethe and Heine. For the populists, the heady brew of German romanticism and the "cultural pessimist" critique of thinkers like Oswald Spengler shaped the orientation of, most obviously and influentially, László Németh. In terms of history, the "German orientation" was used as shorthand (for example, by Németh (1989 [1940]) against the establishment historian and Magyar Szemle ['Hungarian Review'] editor Gyula Szekfü) for excessive sympathy for the Austrian Habsburgs, who were seen to have dominated and repressed Hungarian national aspirations. Germany had at the same time also become a regional power, despite its hobbling by the terms of the World War I peace treaties - and the only one with a revisionist orientation, that could help Hungary regain its lost territories. This accounts for the government's resolutely Germany-oriented foreign policy through the period, and the consequent increasing reliance of Hungary's agricultural economy on German purchases. The flip side of this growing power, however, was the threat that it would dominate and use Hungary for its own purposes. This fear, ultimately borne out over the course of the war years, played a large role in the nationalist "race protection movement" moving from a primarily anti-Jewish orientation in the early 1920 s to a primarily anti-German (including anti-Schwabian ${ }^{5}$ ) one from the late 1920s. This shift is symbolized by the movement's firebrand, Endre Bajcsy-Zsilinszky, who ended his life as a martyr at the hands of Nazi occupiers in late 1944. After Hitler's 1933 seizure of power, Germany increasingly stood, especially to the urbanists, for Nazism, anti-Semitism and extremism. Germany provided to a large extent-parallel to the Jews, at times overshadowing them and at other times being overshadowed by them-Hungary's "constituent Other," an object of both fear and envy. Germany and Germanness, as symbolic qualities, thus existed at a swirling

${ }^{5}$ The Hungarian term sváb ['Schwabian'] is used generally to refer to ethnic German residents on the territory of the historic Hungarian kingdom (also referred to as Danube Schwabians), who settled there in several waves since the time of King István. 
Esbenshade, Richard S. "Symbolic Geographies and the Politics of Hungarian Identity in the 'Populist-Urbanist Debate,' 1925-44." Hungarian Cultural Studies. e-Journal of the American Hungarian Educators Association, Volume 7 (2014): http://ahea.pitt.edu DOI: 10.5195/ahea.2014.174

vortex of meanings and imputations, both positive and negative, which translated into their regular employment in intellectual combat by both urbanists and populists.

The relationship between Germany and Hungary, both the real one and the symbolic or "felt" one, epitomizes and evokes the specter of "backwardness," alluded to above. The question of identity on the margins of Europe cannot be discussed without reference to development and to perceptions of its presence or absence. Andrew Janos has written extensively about what he calls the "demonstration effect" of the adjacent model of West European development on Hungarians (and other East-Central Europeans), which has constantly showed up their own (perceived) inferiority, and created the inevitable tensions around what or who is to be blamed for the gap (Janos 1982, 2000). World-systems theory_into which Janos's analysis, broadly speaking, fits-explains lack of development in the periphery or semi-periphery (to which Hungary is assigned) as a function of the very process of development itself at the core (Wallerstein 1974). Add to this the idea of Europe, which proffers the rewards of development on the basis of equality and justice, and there is ample material for a stew of envy and insecurity. In addition to the need to find scapegoats for the country's failure, this pressure pushed intellectuals into ever-more intensive attempts to compensate in the area of national identity.

Dilemmas of development and backwardness thus both produce and then figure prominently in the symbolic geographies that appear throughout intellectual discourse. This factor works not only between nations in the all-European context, but within Hungarian borders as well. Uneven development between the capital and the countryside produced and pervaded the internal symbolic geographies of Hungarian intellectuals when addressing themes of city and village, an opposition which quickly turned symbolic. To give a simple yet pervasive example, populist writers would consistently situate themselves spiritually in the village and the world of the peasant, even while economic and political necessity forced them into "számüzetés" ['exile'] in Budapest; the urbanists were, for them, the eternal denizens of the morass of the corrupt "pesti kultúra" ['Pest culture'], with its "bulvársajtó" ['boulevard press'] and elitist, superficial entertainments (Illyés 1933b). ${ }^{6}$ For their part, the urbanists often treated the village as part of a general rural wasteland, its populace dependent on prospective salvation from the city, either through migration or adoption of urban values (B. Zsolt 1992 [1939]).

The counter-intuitive but, I believe, productive idea of the "advantages of backwardness," is a potentially productive way to frame these problems. In Alexander Gershenkron's (1962) original formulation the phrase refers to the quick route to industrialization possible for a society - in his case Russia - able to benefit from other countries' having previously traversed the longer and more difficult road. But I wish to invoke something different: a critical take on the situation that forces a "small people" such as the Hungarians to engage in struggles over identity as a substitute for just development - that is, an alternative, valuable view of modernity itself. Moretti recognizes this possibility in Russian literature:

${ }^{6}$ Returning from his sojourn to Budapest, Illyés has entered a completely other (and Other) realm where no one believes his stories of disaster in the countryside, and he has to kick himself to make sure he still experienced them. 
Esbenshade, Richard S. "Symbolic Geographies and the Politics of Hungarian Identity in the 'Populist-Urbanist Debate,' 1925-44." Hungarian Cultural Studies. e-Journal of the American Hungarian Educators Association, Volume 7 (2014): http://ahea.pitt.edu DOI: 10.5195/ahea.2014.174

every issue opens up to opposite viewpoints, even in the same person. And it's also an instance of how geography may, if not exactly determine, at least encourage morphological change: because only a country that was both inside and outside Europe - i.e., only Russia - could call into question modern Western culture, and subject it...to genuine "experiments" (Moretti 1998: 32, original emphasis). ${ }^{7}$

In what follows, I will present aspects of both the populists' and the urbanists' reliance on these powerful, historically constructed geographical tropes, as appearing in their debates with each other and with other political movements and actors. Embedded geographical references and attempts to describe national character were used both for self-legitimation and to delegitimize opponents, but, I will argue, they ultimately point towards multiple critical stances on Hungary's position in the region and the world, and its possibilities to develop and thrive. I will examine the populists' rhetorical forays into anti-colonialism, their staking of claims for Hungarian identity as "neither West nor East," and their imaginings of various alignments for regional solidarity. I will address the "German factor," especially in relation to charges of antiSemitism. I will also explore the urbanists' idea of Europe, which turns out to be more nuanced and complex than one would expect. Finally, I will survey the different sides' conceptions of the deep origins of the Magyars, focusing especially on the "Turanian idea."

\section{Mental Maps and Symbolic Geographies}

Németh's statement quoted in the opening paragraph of this article, one which assimilates the Papuans to the Magyar cause, may seem to be just another of the unpredictable thinker's mercurial flights of fancy; however, there was a method to his madness. Both urbanists and populists were quick to reach for the (mental) atlas when conjuring up descriptions of themselves or their opponents. Urbanist ascendance would lead to soulless Europeanness, while populist projects would pull Hungary into the Balkans. If at times their use of such geographical references seems almost automatic, these intellectuals were extremely conscious of Hungary's place in the geopolitical space of Europe. Trianon had put borders, territory, and location at the front of the political agenda. The search by Hungary's political class for allies in the revisionist struggle, soon centered on Germany, increased this focus, especially as European politics became more belligerent and crisis-ridden.

The Hungarian establishment's loss of faith in the Western powers to address its territorial claims proceeded against a wider backdrop of the crumbling of the legitimacy held by liberal capitalism, and by the colonialism that underpinned it. The populists' harmadik út ['third way'] idea manifested their own critiques of the liberal order; they saw Hungary's adoption of

\footnotetext{
${ }^{7}$ Moretti's “only Russia” unfortunately puts East-Central European countries such as Hungary in the familiar position of being in the shadow of nations with larger and more accessible cultural footprints, left out even of the celebration of "backwardness." Moretti also applies this analysis to Brazil, as shown by the work of R. Schwarz: "the dissonance between Brazilian reality and European ideas, Schwarz goes on, estranged those ideas; and so, for a bizarre twist of history, 'our national oddities became world-historical. . . [perhaps comparable to how, s]ustained by its historical backwardness, Russia forced the bourgeois novel to face a more complex reality" (195, original emphasis).
} 
Esbenshade, Richard S. "Symbolic Geographies and the Politics of Hungarian Identity in the 'Populist-Urbanist Debate,' 1925-44." Hungarian Cultural Studies. e-Journal of the American Hungarian Educators Association, Volume 7 (2014): http://ahea.pitt.edu DOI: 10.5195/ahea.2014.174

many of its tenets in the late Habsburg period as a root cause of national decline. Despite a tendency towards an insular focus on the fate of the Magyars, they also showed an opening to new ideas and tendencies from across the continent and beyond, especially in the person of Németh.

By the 1930s, anti-colonialism as a global movement had begun to raise its head as a force, if one that could as yet show few successes (though the partial victory of the Irish Republican Army lay before Europeans as an example). In his telling of the history of European civilization in his long essay Magyarság és Európa ('Magyardom and Europe'), Németh was unsparing on the ravages of colonialism:

The Spaniards pushing West instead of India found wild islands and [American] Indian cultures ready to be preyed upon. In time, America emerged from this island world, and the silver of the Potosi mines began to flow. In the place of the old Palestinian, Antiochian and Edessian feudal kingdoms now colonial statelets (Mexico, Peru, Bolivia) waiting for looting and exploitation summoned the Conquistador from the other side of the ocean. In the place of the Pisans, the Genovans and the Venetians the Western people of the coasts step in, after the Portuguese and the Spanish the English, French and Dutch.... European culture reached its greatest possible expansion, and sentenced all the rest to death (L. Németh 1989 [1935]: 259. 262).

[A nyugat felé haladó spanyolok India helyett vad szigeteket s prédakész indián kultúrákat találnak. Idöbe kerül, amíg e szigetvilágból Amerika kibontakozik, s a potosi bányák ezüistje csorogni kezd. A régi palesztinai, antiokhiai, edesszai hübéres királyságok helyén most kirablásra és kiaknázásra váró gyarmatállamocskák (Mexikó, Peru, Bolívia) hívják a konkvisztádort az óceán túlsó partjára. A pisaiak, genovaiak, velenceiek helyébe a Nyugat parti népei lépnek, a portugálok és spanyolok után az angolok, franciák, hollandok. . . Az európai kultúra elérte lehetö legnagyobb kiterjedését, s haldoklásra itélte az összes többit.]

In his 1939 essay Kisebbségben ['In the Minority'], he quotes Ady to the effect that

The devil take it, capitalist civilization is not the non plus ultra, and it doesn't make a society spirited and settled that it follows in the footsteps of, for example, today's France or Germany. China is no slouch, and tormented India is such a deep, powerful force, that today we don't even suspect it (L. Németh 1942: 60$61)$.

[Ördögbe is, a kapitalista civilizáció nem a non plus ultra, s egy társadalmat nem az tesz lelkessé és megállapodottá, hogy például a mai Franciaország vagy Németország nyomában jár-e. Kína se kutya, s a sanyargatott India olyan mélységes, hatalmas erejü, hogy ma még nem is sejtjük.]

Németh, as one so steeped in European culture himself, had his biases and blind spots towards non-Western peoples; but his sense of the miseries past and present suffered by the nation and 
Esbenshade, Richard S. "Symbolic Geographies and the Politics of Hungarian Identity in the 'Populist-Urbanist Debate,' 1925-44." Hungarian Cultural Studies. e-Journal of the American Hungarian Educators Association, Volume 7 (2014): http://ahea.pitt.edu DOI: 10.5195/ahea.2014.174

the nép ['people,' in the sense of the German Volk] also give him a sensitivity to the depradations lurking within that culture. And, as part of a younger, modern-oriented generation, he was attuned to the disruptive potential, at least discursively, of anti-colonialism. By associating his urbanist opponents with the historical forces of oppression - however politically powerless they may have actually been in the interwar Hungarian neo-feudal order - and himself with those of a nascent global justice movement, he was able to assemble added discursive legitimacy for his ideas and his analysis.

Politically, an alignment with or orientation towards the East or "Asia" was hardly a credible stance for the populists. But they could chip away at the walls of the citadel of the Western cultural orientation by pushing a position of "neither East nor West": the bridge role, the border identity discussed earlier, building on a long history. Writing in the journal Kelet Népe ['People of the East'] ${ }^{8}$, populist Géza Féja, describing historical "castes" in the Hungarian countryside, stated "Europe! Not even Budapest can be felt from here. This is not West, but also not East" [Europa! Még Budapest sem érezhetö itten. Ez nem Nyugat, de nem is Kelet] (Féja 1937: 32). Another article in the same journal trod a well-worn path in setting the Western orientation against the essential nature of the nép ['nation' or 'people'], blaming Hungary's lack of integrated and authentic "szellemi kultúra" ["spiritual culture'] on the "lateiner-német" ['Classical-German'] orientation of the elite (Barsi 1938). The war years saw a turn from culture to issues of national survival. In a return to the egyke issue, an article in the right-populist Sorsunk ['Our Fate'] contrasted Eastern fertility and Western restraint, arguing that Hungary is on the border between the two. Calling for resistance to Western materialism and individualism, author Zsigmond Zsolt argued that Hungarians thus needed to fight the Western tendency in order to survive (Zs. Zsolt 1942). Even the more "moderate" wing of the populists employed the trope of "neither East nor West." An article in Illyés's wartime journal Magyar Csillag ['Hungarian Star'] on népi ['popular' or 'populist'] culture opened with quotes from nineteenth century literary giants Ferenc Kölcsey and Mihály Vörösmárty on the Magyars as neither West nor East — or as both (Vargyas 1943). (Even the establishment was susceptible to taking such a position, at least rhetorically, as in the article in Magyar Szemle cited earlier (Keresztury 1934).)

A more coherent program or project pursued by the populists was that of an alliance of Central/East European "small states," and an identity tied to this orientation. While not directly contesting a Western orientation for Hungary, this stance did pose a clear alternative to the urbanists' unflagging Western European orientation, as well as to the regime's supplications to any potentially revisionist power (ultimately, Nazi Germany and Fascist Italy). Such ideas can be traced back to the somewhat improbable "turáni-szláv parasztállam" ['Turanian-Slav peasant state'] advocated by Dániel Fábian of the BMT, and dismissed by establishment historian Gyula Szekfü in the pages of Magyar Szemle (Szekfü 1929). But the BMT also acted on its ideas by engaging with the situation of the Magyar minorities across the borders, seeking out allied groups like Sarló ['Sickle'] in Slovakia and Erdélyi Fiatalok ['Transylvanian Youth']; these contacts also led them towards new assessments of other nationalities. Németh was an early and consistent advocate of central European solidarity and cultural awareness of neighboring

\footnotetext{
${ }^{8}$ The title of this core populist journal was a safe rhetorical nod which harkened back to nineteenth-century reformer István Széchenyi (see Rac in this issue of Hungarian Cultural Studies).
} 
Esbenshade, Richard S. "Symbolic Geographies and the Politics of Hungarian Identity in the 'Populist-Urbanist Debate,' 1925-44." Hungarian Cultural Studies. e-Journal of the American Hungarian Educators Association, Volume 7 (2014): http://ahea.pitt.edu DOI: 10.5195/ahea.2014.174

peoples, as expressed in both Magyarság és Európa and, to a lesser extent, in Kisebbségben. In another 1939 piece, he expressed both an acquiescence to "Europeanist" categories and a resistance to defining them in a "West-worshipping" way:

Whatever the outcome of the great struggle for hegemony taking place in the world will be: they will hardly be asking the small peoples if they like the result. Whether English, Germans, or Russians realize their plans, [the small peoples'] role will clearly be one of accommodation...We have to be European, of course. But in such a way as the French or the English: as befitting the place. For them western, for us eastern European. Because true Balkanism is not being at home in the Balkans, but being there and not being at home (Juhász 1983: 84). ${ }^{9}$

[Akármi lesz a világban folyó nagy hegemonia-harcnak a vége: a kis népeket aligha kérdik meg, hogy tetszik-e nekik az eredménye. Angolok, németek vagy oroszok szabják-e Európára a maguk tervét: az ö szerepük nyilván az alkalmazkodás lesz. . Európainak kell lennünk, természetes. De úgy, ahogy a franciák vagy az angolok: a helyhez illöen. Nekik nyugat-, nekünk keleteurópaian. Mert az igazi balkanizmus nem: otthon lenni a Balkánon, hanem ott lenni és otthon nem lenni.]

Another populist, Zoltán Szabó, proposed "Kárpátaljai Európa" ['Carpathian Europe']. This imagined region was territorially more restricted than the ones envisioned by the BMT and Németh, but with a stronger sense of Magyar leadership — and, not coincidentally, corresponding more to the borders of "historic Hungary." As he wrote: "This is then the area, which is geographically middle Europe; ethnographically, small peoples' Europe; socially, peasants' Europe" [Ez a terület tehát, mely geográfiailag középsö Európa, néprajzilag: kis népek Európája, társadalomrajzilag parasztok Európája] (Z. Szabó 1939: 11, original emphasis). This conception was roundly debated in the first months of 1940 in the pages of the daily Magyar Nemzet ['Hungarian Nation'] and elsewhere; intellectual historian Gyula Juhász cites one participant listing up all the previous configurations that had been proposed: Danube Valley; Danube Basin; Danube Confederation ( $19^{\text {th }}$ century revolutionary Lajos Kossuth's idea); the Danubian United States (bourgeois radical and proto-urbanist Oszkár Jászi's; also known as "Eastern Switzerland"); Danube-Europe; East-Central Europe (Géza Féja); and East-Europe (composer and folk song collector Béla Bartók, and, with his own particular slant, proto-populist Dezső Szabó) (Juhász 1983: 90). ${ }^{10}$ The urbanists were themselves not immune to the lure of such

${ }^{9}$ The original article is László Németh, “Ágak és gyökerek” ['Branches and roots'], Magyarország ('Hungary’), 23 December 1939.

${ }^{10}$ The original article is István Gál, Magyar Nemzet ['Hungarian Nation'], 4 January 1940. These are in addition to the more general plans circulating around Europe, which Gál also mentions: Mitteleuropa, predating the Nazi conception; "Zwischeneuropa," from the beginning of the 1930s, and influencing Németh; "Südosteuropa"; "L’Europa Centrale" (from the mid-1920s, in essence an anti-German alliance); and "Zentraleuropa." 
Esbenshade, Richard S. "Symbolic Geographies and the Politics of Hungarian Identity in the 'Populist-Urbanist Debate,' 1925-44." Hungarian Cultural Studies. e-Journal of the American Hungarian Educators Association, Volume 7 (2014): http://ahea.pitt.edu DOI: 10.5195/ahea.2014.174

visions. ${ }^{11}$ Of course, above - or, in some cases, behind (though the populists quite explicitly aimed theirs distinct from or even against Germany's) - all of these lurked the Hitlerian version of Mitteleuropa, soon to be realized.

This brings up the German factor, which, as I argued previously, cannot be ignored, though I will focus on its symbolic content. The hostility of the "race-protection movement" towards Germany, and thus towards the official government orientation, began with Endre Bajcsy-Zsilinszky's crusade in the pages of his journal Elöörs ['Vanguard']. From the first issues of the journal in 1928, he highlighted the connection between the inevitable imperial aspirations of an only temporarily hobbled Germany and the Schwabian minority in Hungary. He summed up his position in a front-page article entitled "The German Danger" (Bajcsy-Zsilinszky 1928b; see also Bajcsy-Zsilinszky 1928a; Karap Kovács 1928; Áfra Nagy 1929). The historically conditioned German expansionary impulse had sown ethnic German settlers throughout Eastern and Southeastern Europe. The likewise historical suppression of Magyar aspirations by the German Habsburgs, coupled with the growing influence of the "German spirit" in the Hungarian middle class and public life, suppressed the realization of Magyar national and racial identity. As a result (showing remarkable prescience!), the country must prepare for the Anschluss. ${ }^{12}$ The theme was soon picked up by Dezső Szabó and others. Thus it is not surprising to see, in a leader column of the right-populist Magyar Út ['Hungarian Way'] for New Year's Day 1937, entitled "Kik vagyunk? ..." ['Who Are We? . .'], the first pronouncement: "Nem vagyunk svábok" ['We are not Schwabians'], and only thereafter, ranked second, the expected "Nem vagyunk zsidók" ['We are not Jews'] (Pap 1937). This parallelity makes clear how the urbanists could be tarred with the same brush, as another "Fifth Column"-type force threatening national consciousness and unity — and as equally dangerous carriers of urbanness, liberalism, modernity - ignoring the irony of the picture of "Jews" and Nazis allied against the Magyars. The populists, more sensitive to charges of anti-Semitism (which, from 1934, were consistently hurled their way by various urbanists), took a different tack. They threatened that if their opponents insisted on calling the "child"- the movement which the populist writers were giving birth to - "Kurt," then it would be likely to grow up "Kurt" and not "János"- that is, more "German" than Hungarian (Illyés 1990 [1934]: 113). But the urbanists continued to use the "German card"; for example Fejtö - otherwise one of the more cautious in leveling such indictments - charged the populists with being "mélységesen német" ['deeply German'] (Fejtö 1936: 219).

Geographical references wielded at the slightest provocation, various utopian ideas for regional unity, an anti-German stance, even Németh's assaults on colonialism - these don't add up to a coherent populist strategy. But the urbanists did have a cogent symbolic-geographical project, and it was constant and unyielding: putting Hungary on "the road to Europe." If the concrete content of such "Europeanism" was left vague and abstract-beyond opposition to “"nemzeti' és 'faji' szlogenek" ["“national" and "racial” slogans'] (Remenyik 1937a: 5) - the endeavor itself was emphasized over and over again. What was to be left behind was of course much clearer: Hungary as it existed as a backwards state, and especially retrograde attitudes

\footnotetext{
${ }^{11}$ See discussion of Hatvany's article, below.

${ }^{12}$ Note the clever appropriation from the German idea of the corrosive cultural effects of the "Jewish spirit," in play since at least Richard Wagner.
} 
Esbenshade, Richard S. "Symbolic Geographies and the Politics of Hungarian Identity in the 'Populist-Urbanist Debate,' 1925-44." Hungarian Cultural Studies. e-Journal of the American Hungarian Educators Association, Volume 7 (2014): http://ahea.pitt.edu DOI: 10.5195/ahea.2014.174

(such as the populists" "peasant romanticism") about society and the way forward. The recognition that "Europe in this context is naturally not a geographical concept, but the more developed culture, the yearned-for urbanity, the object of desire and symbol of the not-able-tobe-born bourgeois Hungary" [Európa ebben az összefüggésben természetesen nem földrajzi fogallom, hanem a fejlettebb kultúra, az áhítozott urbanitás, a megszületni nem tudó polgári vágyképe és szimbóluma] (A. Németh 1990 [1937]: 77), in no way dampened the urbanists' exertions to reach it.

Within the general profile of absolute European/Western orientation, there was, however, a more nuanced appreciation of the ambiguous nature of that legacy. Urbanists also debated its worthiness as a guiding light among themselves. For example, in a response to Zsigmond Remenyik, an editor and frequent writer for the core urbanist journal Szép Szó ['Beautiful Words'], Bertalan Hatvany, a writer as well as an urbanist Maecenas, pointed out the violence and oppression that accompanied the Western push for freedom. He even defended the "civilized" aspect of nationalism, as "the beautiful and noble flower of culture" [a kultúrának szép és nemes virága], against the imperialism that stretched from Alexander the Great through Rome to the present. Along the way he recognized the spiritual value of Asian civilization, if also the comparable state violence that inevitably superseded it. Finally, while not rejecting the Western example out of hand, he advocated an evolution of Lajos Kossuth's Danube Confederation idea, an alliance of "the humanist and progressive thinkers of the Danube valley" [A Duna völgyének humanista és progresszív gondolkodói] (Hatvany 1937a: 102, 104). Remenyik's response respectfully reinforced his universalist position, though he couldn't seem to avoid denouncing the "European wild ones, European Tasmanians, Senegalians, Batus and Vedas, the garbage of our common, beautiful home" [Európai vadak, európai tazmánok, szenegálok, batuk és veddak, egyszóval közös, szép hazánk szemete] (Remenyik 1937b: 105). Hatvany replied that, like Remenyik, he too "believes in the new and better Europe, the Europe of democracy and social progress" [új és jobb Europát, a demokrácia és a szociális haladás Európáját], but one in which "the political concept of national self-centeredness will make space for the self-centered freedom of national cultures" [a namzeti öncélúság politai fogalma helyet fog adni a nemzeti kultúrák öncélú szabadságának] (Hatvany 1937b: 108). The poet Attila József, BMT activist-turned-urbanist, in an earlier review of Hatvany's book Ázsia lelke ['The Soul of Asia'] (Hatvany was also a self-styled Oriental scholar), perhaps most astutely sensed the limits and contradictions of the urbanists' European project. He commented that Hatvany was "taking refuge from his Europeanism . . in the soul of Asia" [önön európaiságától . . menekül Ázsia lelkébe] (József 1936: 70).

Finally, a vast theme that is intimately related, but can only be touched on here, is the search for ancient ethnic origins. The primary contenders for the ancestry of the Magyars were the "Turanian"-including Finns, Turks, Tatars, Bulgarians, Uzbeks and Magyars (Lendvai 2003 [1999]: 385) — which generally accompanied a firm Asian orientation, and the more scientifically verified, European-oriented "Finno-Ugric" heritage, generally accepted today, at least linguistically; with the 'Scythian,' a more fantastical possibility, but one still today beloved in 
Esbenshade, Richard S. "Symbolic Geographies and the Politics of Hungarian Identity in the 'Populist-Urbanist Debate,' 1925-44." Hungarian Cultural Studies. e-Journal of the American Hungarian Educators Association, Volume 7 (2014): http://ahea.pitt.edu DOI: 10.5195/ahea.2014.174

hard-core nationalist circles. ${ }^{13}$ There were also more oddball theories, such as one appearing in Kelet Népe arguing that the Magyar spirit had also been formed by Buddhist-Mongolian elements. Another notion maintained that Magyardom was composed of two types: an Ugric, tame, modest, but with a complicated soul; and a Turkic, proud, physically courageous and unrestrained — both however 'Mongol,' though differing from the Mongolian (Barsi 1936; Pálóczi Horváth 1940). ${ }^{14}$ Intellectual historian Miklós Lackó has argued that reaching back for primordial roots is a sign of anxiety about status as a nation, and pointed out the "regression" in Hungary from a turn-of-the-century historical emphasis on the state-building medieval period to one on searching for the ethnic origins of the Magyars. What's more, the assertion of "Asian" or "Eastern" roots, he claims, is more amenable to the race ideas that came to the fore than European/Western ones. It is in this context that backwardness vis-à-vis Europe was turned into something positive, representing in the eyes of the holders of such ideas a higher value system than the modernity which Hungary had supposedly rejected (Lackó 1996: 264-65). ${ }^{15}$ The populists were on the whole not much attracted to the intense investigations and debates engaged in by many who saw it their mystical and sacred calling to trace the history of the nép back "to the beginning," but several prominent populists peeled off in this direction from the late 1930s. The urbanists predictably viewed the whole enterprise with distaste, though while seeing such a focus as an unproductive diversion, did not go so far as to dismiss the scientific aspect of linguistic and ancient historical studies - to the origins of which their direct forebears contributed to a surprising degree.

I have already mentioned the Turanian idea in the context of the BMT, advanced there however without much depth or serious historical claim, more than anything as a signal of their commitment to a "deep" idea of Magyarness. But the Turanian Society was actually formed not by hotheaded romantics but by esteemed Orientalists in 1910, including Ármin Vámbéry, father of urbanist Rusztem. (Its first president was Count Pál Teleki, a thoroughly establishment figure who as Foreign Minister would famously commit suicide upon the Nazi invasion of Yugoslavia in 1941.) Its charter was to

Research and illuminate, scientifically and in practice, Turania, our ancient home which defines our great past and perhaps even greater future. In Europe and in

\footnotetext{
${ }^{13}$ The Scythians are most likely a Persian-related people from the Eurasian steppe, mentioned in Greek times. Rightist newspapers often had regular columns entitled "Scythian," and it survives today as a moniker for nationalist newsletters, clubs, and curio shops.

${ }^{14}$ A more sinister variation, encapsulated by the designation "Hungarista" ['Hungarist'], which encompassed origins, regional mission, and mystical identity and calling, was spawned by Ferenc Szálasi, leader of the native fascist Arrow Cross (with inevitable variations and contestations on the that end of the political spectrum).

${ }^{15}$ By 1938, a whole raft of exotic-sounding societies had arisen, including the "turáni egyistenhit" ['Turanian Monotheists'], the "virrasztó-koppányság" ['Vigilant Koppány-dom'] (Koppány was one of the original leaders of the Magyar conquest, persecuted by István because he refused to give up paganism), the "turáni szabadvadászok" ['Turanian Free Hunters'], the "csodaszarvas-várók" ['Waiters for the Magic Deer'], and the "Árpád-népe" ['People of Árpád’] movement (Juhász 1983: 13).
} 
Esbenshade, Richard S. "Symbolic Geographies and the Politics of Hungarian Identity in the 'Populist-Urbanist Debate,' 1925-44." Hungarian Cultural Studies. e-Journal of the American Hungarian Educators Association, Volume 7 (2014): http://ahea.pitt.edu DOI: 10.5195/ahea.2014.174

Asia, from Dévény to Tokyo, in the past, present and future, making friends and allies for the good of ourselves and the whole world (quoted in Gy. Németh 1931: 132). ${ }^{16}$

[Kutatni és felvirágoztatni, tudományosan és gyakorlatilag Turánt, nagy multunkat és talán még nagyobb jövőnket jelentö öshazánkat. Európában és Ázsiában, Dévénytöl Tokióig, multban, jelenben és jövöben, barátokat és szövelségeseket szerezve magunk és az egész világ javára.]

After the war the society split into three, with the more 'race-protection'-oriented forming the Turanian Alliance, to

teach the Magyar person that the Magyar is a Turanian-origin people, can be proud of its origin, is not a vagabond fragment of a people of uncertain origin, but speaks in an ancient language about its praiseworthy history, its love of homeland and high-souled love of humanity. Not a homeless Gypsy or Jew, parasitical on others, but a great nation of noble origins (Gy. Németh 1931: 133).

[meg akarja tanitani a magyar embert arra, hogy a magyar turáni eredetü nép, büszke lehet eredetére, nem jött-ment, bizonytalan eredetü néptöredék, hanem ösi nyelven beszél dicsöséges történelemröl, hazaszeretetröl és müvelt lelkü emberszeretetröl. Nem hontalan, másokon élösködö cigány vagy zsidó, hanem ösnemes, nagy nemzet.]

The Turanian Alliance shriveled within a few years, but in part due to renewed advocacy in the nationalist press - for example, in Elöörs (Udvardy 1929; Borsutud 1929b, 1929c, 1929a; for a dissenting voice, see -uk-1929) — grew again from the beginning of the '30s.

The established, "scientific" response to the Turanian idea was the assertion of FinnoUgric origins, for example in a Magyar Szemle book review rejecting the "hazardous mirage" of Turanianism (Trócsányi 1930; see also Eckhardt 1937). ${ }^{17}$ But the "Finnish connection" had its own emotional attraction as well, especially to the populists, undoubtably due to the Finns' similarly dangerous location between Nazi Germany and the Soviet Union, and their fellow

\footnotetext{
${ }^{16}$ A statement at a January 1914 assembly was even grander: "[A]fter the golden age of Germandom and Slavdom, the flowering of Turaniandom follows. That great and difficult, but praiseworthy task waits on us, Magyars, the Western representatives of the giant awakening power (Turaniandom), that we become the spiritual and economic leaders of 600 million-strong Turaniandom" [a germánság és szlávság fénykora után a turánság virágzása következik. Reánk, magyarokra, ez óriási ébredezö hatalomnak (a turánságnak) nyugati képviselőire vár az a nagy és nehéz, de dicsö feladat, hogy a hatszázmilliós turánságnak szellemi és gazdasági vezérei legyünk) (Gy. Németh 1931: 132, quoting Alajos Paikert).

${ }^{17}$ Eckhardt was reviewing Miklós Zsirai, Finn-ugor rokonságunk ('Our Finno-Ugric Kinship') (1937). Another reason cited for the Right challenging the Finno-Ugric roots of the Hungarian language, and by extension of the Magyars as an ethnic nation, was that most of the linguists in the classical generation who came to that determination, like Vámbery, were themselves of Jewish or Schwabian origin (Lendvai 2003 [1999]: 347).
} 
Esbenshade, Richard S. "Symbolic Geographies and the Politics of Hungarian Identity in the 'Populist-Urbanist Debate,' 1925-44." Hungarian Cultural Studies. e-Journal of the American Hungarian Educators Association, Volume 7 (2014): http://ahea.pitt.edu DOI: 10.5195/ahea.2014.174

"small people," "Central European," relatively undeveloped status. Thus we have worshipful examples like Pál Gulyás's long "Road to the Kalevala," a celebration of the Finnish supposed ancient oral epic (now agreed to have been invented in the nineteenth century) in the populist flagship journal Válasz ['Response'], or an article entitled "Suomi lelke" ['The Soul of Suomi'] in Kelet Népe (Gulyás 1937; Csekey 1940; see also Széchenyi 2002: 59). The most intensive engagement with Finland and Finnish language and culture as a key connection for Hungarians was that of populist János Kodolányi, who spent several long spells in Finland, learned the language and translated several literary works into Hungarian (Kodolányi 1937, 1938, 1939). But this commitment did not bind Kodolányi to a more "Western" or even "Central" orientation: in an article entitled "People of the East," he counterposed the German idea of an északi faj ['northern race'] with his own of the Magyars' Eurázsiai lélek ('Eurasian soul'), which he equated with Németh's idea in Kisebbségben of mélymagyarság ['deep-Magyarness'] (Kodolányi 1941). Though he did not even mention Turanianism, Zoltán Szabó imputed that association to Kodolányi with the title of his response, "Turania and Eurasia," in which he accused him of "looking towards the West only with hatred" ["Pillantása csak gyülölettel száll Nyugat felé"], and of propagating the same kind of exclusion as Németh (Z. Szabó 1941: 11). ${ }^{18}$

\section{Conclusions}

As Hungarian intellectuals' continuing speculations about who they were and where they belonged show, debates between and among populists and urbanists from the late 1920s into the 1940s both perpetuated and opened up different "symbolic geographies," putting Hungary on fluid mental maps where it could be pulled between East and West, Asia and Europe. These debates may initially seem to cleave neatly into familiar binaries: essentialists $v s$. rationalists; pure/exclusionary (quasi-racial) conceptions of Magyardom vs. inclusive ones; partisans of "Asian" or "Eastern" roots (Turanian, Finn, Scythian, etc.) vs. absolute Europeanists. But, in tune with their abstract nature and the highly charged and constantly shifting political field in which they were employed, these concepts were much less stable and identifiable as the province of one side or the other. Populists like Lászlo Németh constantly invoked Europe, but critically and at arm's length. Urbanists also occasionally showed a critical perspective towards Europe and its historical effect on Hungary; or exhibited an affinity for Asia, as did Bertalan Hatvany, and consequently opened up cracks in the armor of their rationalism. Conflicts such as those between János Kodolányi and Zoltán Szabó expose the populist orientation as likewise not completely stable. The intensive involvement of "outside" figures such as Gyula Szekfü and Endre BajcsyZsilinszky point to the dangers of seeing in binaries: it was a more complex field, with at least a three-way competition or conflict, itself complicated by shifting alliances.

As changeable and manipulable as the contestation was, it took place within powerful, and already existing fields which were historically constructed over centuries of complicated and unequal relations between Hungary and several surrounding powers, and within a stratified and oppressive Hungarian society. And this history was continuing in the interwar period. Most Hungarians were increasingly disillusioned with the West, because of Trianon, but also because

\footnotetext{
${ }^{18}$ Szabó otherwise had quite high regard for Németh; they had traveled together to Romania just a couple years earlier (Z. Szabó 1939: 9).
} 
Esbenshade, Richard S. "Symbolic Geographies and the Politics of Hungarian Identity in the 'Populist-Urbanist Debate,' 1925-44." Hungarian Cultural Studies. e-Journal of the American Hungarian Educators Association, Volume 7 (2014): http://ahea.pitt.edu DOI: 10.5195/ahea.2014.174

of a sense of impotence and abandonment as the feeling of impending war increased. Reaching for an "Eastern" or otherwise separate identity was not just part of a process of radicalization of nationalism, spiked with fascist ideological intrusions. It was also the result of independentminded Hungarians feeling abandoned once again by the West, this time to the Nazi sphere of influence (Juhász 1983: 83). Thus "Eastern (or Central, or Danubian, etc.) European Solidarity" had a real basis in contemporary political events; and there was a strong sense that the big powers, with their search for client states, fickle alliances and general meddling, were sabotaging even this. Németh's use of anti-colonialism against both the West and Europhile urbanists was a brilliant move, turning the charges of "Easternness" or "backwardness" into rallying criesdemonstrating how the unequal relationship had powerful discursive possibilities. Within this whole matrix, (symbolic) Germany was the enduring wild card. It was fodder for charges on all sides, and a source of knowledge and culture, both classic and revisionist.

To ridicule the many colorful and seemingly wild expressions of identity, the fantastic gymnastics carried out across the mat of mental maps, is easy, but doesn't get us closer to understanding the dynamics of intellectual combat and cultural formation, and I hope I haven't fallen into that trap. A piece in the 2005 volume Mi a magyar? ['What is the Hungarian?'] by Péter Esterházy, one of Hungary's greatest and most complex contemporary writers, in pleading for a 'common-sense' approach, seems to both engage in this ridiculing stance and to go beyond it.

I never understood . . this Magyardom-Europe conflict. . . Anything I do is at the same time Magyar and European, there is no Etelköz [the supposed place where the Magyars originated] ancient reflex of ours that wouldn't be that. By definition it belongs in the nonexistent inventory: Europe became what it is also by means of the Magyars. Every nation understands (must understand) that grandiose image, which is Europe and which at the same time contains the different kinds of understandings about it, in its own way (Esterházy 2005: 62).

[Sosem értettem . . ezt a magyarság-európaiság konfliktust. . . Bármi, amit teszek, az egyszerre magyar és európai, nincsen az az etelközi ösreflexünk, amely ne volna az. Per definitionem tartozik a nem létezö inventárba: Európa a magyarok által is lett az, ami. Minden nemzet a maga módján fogja fel (kell fölfognia) azt a grandiózus képzödményt, amely egyszermind tartalmazza a róla szóló különféle fölfogásokat is.]

The conflict, and the question spawned by it, is in many ways just as vital and contested in the early $21^{\text {st }}$ century as in 1939 , as this ambivalent volume, despite its opening testimony to triumphal Europeanism and its caution, attests to by its very existence. As long as there are unequal relationships between powers, regions, countries and peoples, as long as there are geopolitics, local politics, culture and struggle, identity questions will continue to be contested. In Hungary, this will happen on a template, a set of "mental maps," greatly contributed to by early- and mid-twentieth century populists, urbanists and others in their sphere of influence. 
Esbenshade, Richard S. "Symbolic Geographies and the Politics of Hungarian Identity in the 'Populist-Urbanist Debate,' 1925-44." Hungarian Cultural Studies. e-Journal of the American Hungarian Educators Association,

\section{Works Cited}

Ady Endre. 1905. "Ismeretlen Korvin-kódex margójára" ['On the margin of an unknown Corvin Codex']. Figyelö ['Observer']: 217-20.

Dr. Áfra Nagy János. 1929. "A magyar-német viszony a magyarság szempontjából” ['The Hungarian-German relationship from the point-of-view of Magyardom'], 4 parts. Elöörs ['Vanguard'] 2.27 (6 July): 13-14; 2.28 (13 July): 15-16; 2.29 (20 July): 11-12; and 2.30 (27 July): 12-13.

Anderson, Benedict. 1991. Imagined Communities: Reflections on the Origins and Spread of Nationalism. Revised ed. London and New York: Verso.

Bajcsy-Zsilinszky Endre. 1928a. "A magyar-német viszony és a magyarországi német kisebbség" ['The Magyar-German relationship and the German minority in Hungary']. Elöörs ['Vanguard']. 1.5 (14 April): 1-3 . 1928b. "A német veszedelem" ['The German danger']. Elöörs ['Vanguard'] 1.24 (26 August): $1-4$.

Barsi Dénes. 1938. "Értelmi és érzelmi válság” ['Spiritual and emotional crisis']. Kelet Népe ['People of the East'] IV.5 (May): 253-60. . 1936. "Magyar faj és tudathasadás" ['The split in Magyar race and consciousness'] (pt. 3). Kelet Népe ['People of the East'] 2.4 (May): 1-4.

Borsutud [pseud.]. 1929a. "Turáni eszme és Eurázia" ['The Turanian idea and Eurasia']. Elöörs ['Vanguard'] 2. 44 (2 November): 12.

. 1929b. "Turáni gondolat és nemzeti radikálizmus" ['Turanian thought and national radicalism']. Elöörs ['Vanguard'] 2.25 (22 June): 12.

. 1929c. "Turáni kultúrpolitika" [‘Turanian cultural policy’]. Elöörs ['Vanguard'] 2.31 (3 August): 12.

Csebi Pogány Béla. 1929. "Magyarország kelet-európai hivatása" ['Hungary’s East European calling']. Új Magyar Föld ['New Hungarian Land'] 2: 13-27.

Csekey István. 1940. "Suomi lelke" ['The Soul of Suomi']. Kelet Népe ['People of the East'] 6.6 (15 March): 15.

Darnton, Robert. 1994. "Sex for Thought." The New York Review of Books (22 December). 6574.

Eckhardt Sándor. 1937. "Nyelvrokonaink" ['Our linguistic relatives']. Magyar Szemle ['Hungarian Review'] 31.3(123) (November): 228-33.

Esbenshade, Richard S. 1997. "The Discreet Charm of the 'Missing Bourgeoisie': Fitting Eastern Europe and the Ottoman Empire into Western Models of Modernity." Unpublished manuscript.

Esterházy Péter. 2005. "Mi a mi?" ['What is the what?']. In Mi a magyar? ['What is the Hungarian?']. Ed. Ignác Romsics and Mihály Szegedy-Maszák. Budapest: Habsburg Történeti Intézet - Rubicon Kiadó: 57-66.

Féja Géza. 1937. "Basák, bégek, janicsárok" ['Pashas, Begs and Janissaries']. Kelet Népe ['People of the East'] III.2 (February): 29-33.

Fejtő Ferenc. 1936. "Sziget és tengér" ['Island and sea']. Nyugat ['West'] 29.3 (March): 216-23. Gal, Susan. 1991. "Bartok's Funeral: Representations of Europe in Hungarian Political Rhetoric." American Ethnologist 18.3: 440-58. 
Esbenshade, Richard S. "Symbolic Geographies and the Politics of Hungarian Identity in the 'Populist-Urbanist Debate,' 1925-44." Hungarian Cultural Studies. e-Journal of the American Hungarian Educators Association, Volume 7 (2014): http://ahea.pitt.edu DOI: 10.5195/ahea.2014.174

Gershenkron, Alexander. 1962. "Reflections on the Concept of 'Prerequisites' of Modern Industrialization." Economic Backwardness in Historical Perspective, a Book of Essays. Cambridge, Mass.: Belknap Press.

Gulyás Pál. 1937. "Út a Kalevalához" ['Road to the Kalevala']. Válasz ['Response'] 4.4: 195219

Hanebrink, Paul. 2006. In Defense of Christian Hungary: Religion, Nationalism, and Antisemitism, 1890-1944. Ithaca, NY: Cornell University Press.

Hatvany Bertalan. 1937a. "Dunamenti Európa" ['Danubian Europe']. Szép Szó ['Beautiful Words']. 5.2(17) (September): 97-104. 1937b. "Viszonválasz" ['Counter-response']. Szép Szó ['Beautiful Words']. 5.2(17) (September): 108.

Illyés Gyula. 1933a. "A magyarság pusztulása" ['The destruction of Magyardom']. Nyugat [West]. XXVI (15 October): 337-44. . 1933b. "Pusztulás. Uti jegyzetek" ['Destruction: Travel notes']. Nyugat ['West']. XXVI (15 September): 189-205. . 1990 [1934]. "Szellemi vérvád" ['Intellectual blood libel']. Magyar Hirlap ['Hungarian Newspaper']. 3 June. In A Népi-Urbánus Vita Dokumentumai 1932-1947 ['Documents of the populist-urbanist debate 1932-1947'] Ed. Péter Nagy Sz. Budapest: Raketa. 112-15.

Janos, Andrew. 2000. East Central Europe in the Modern World: The Politics of the Borderlands from Pre- to Postcommunism. Stanford, Calif.: Stanford University Press. . 1982. The Politics of Backwardness in Hungary, 1825-1945 Princeton, N.J.: Princeton University Press.

Jobbitt, Steven. 2011. "Playing the Part: Hungarian Boy Scouts and the Performance of Trauma in Interwar Hungary," AHEA: E-Journal of the American Hungarian Educators Association 4 (2011): 1-15.

József Attila. 1936. “Azsia lelke” [“Asia’s soul’]. Szép Szó [“Beautiful Words’] 1.1 (March): 68 71.

Juhász Gyula. 1983. Uralkodó eszmék Magyarországon 1939-1944 ['Ruling ideas in Hungary, 1939-1944']. Budapest: Kossuth.

Dr. Karap Kovács Ernő. 1928. “Az Anschluss kérdéséhez” ['On the Anschluss question']. Elöörs ['Vanguard'] 1.23 (19 August): 7-8.

Keresztury Dezső. 1934. "Kelet és nyugat között. A magyar lét kettős szemlélete” ['Between East and West: The double perspective of Magyar existence']. Magyar Szemle ['Hungarian Review'] 21.2(82) (June): 142-54.

Kodolányi János. 1937. "A finn 'szegény paraszt"” ['The Finnish "poor peasant”'], pt. 1. Független Kisgazda ['Independent Smallholder'] (26 December), 6. 1938. "A finn 'szegény paraszt”" ['The Finnish "poor peasant”'], pt. 2. Független Kisgazda ['Independent Smallholder'] (2 January), 5. $163-78$ . 1941. "Kelet népe" ['People of the East']. Sorsunk ['Our Fate'] 1.3 (July-September): 1939. Suomi titka ['The secret of Suomi']. Budapest: Magyar Élet.

Kürti, László. 2001. The Remote Borderland: Transylvania in the Hungarian Imagination. Albany: State University of New York Press.

Lackó Miklós. 1996. "Bujdosó vagy szabságszerető realista? Írások és viták a nemzeti jellemről” ['Fugitive or freedom-loving realist? Writings and debates on the national character']. Sziget 
Esbenshade, Richard S. "Symbolic Geographies and the Politics of Hungarian Identity in the 'Populist-Urbanist Debate,' 1925-44." Hungarian Cultural Studies. e-Journal of the American Hungarian Educators Association, Volume 7 (2014): http://ahea.pitt.edu DOI: 10.5195/ahea.2014.174

és külvilág: Válogatott tanulmányok ['Island and outer world: Selected Essays']. Budapest: MTA Történettudományi Intézete: 260-304.

Lendvai, Paul. 2003 [1999]. The Hungarians: A Thousand Years of Victory in Defeat. Trans. Ann Major. Princeton, N.J.: Princeton University Press.

McNeill, William H. 1964. Europe's Steppe Frontier 1500-1800. Chicago and London: University of Chicago Press.

Moretti, Franco. 1998. Atlas of the European Novel 1800-1900. London and New York: Verso.

n.a. 1928. Ifjú szívekben élek. A magyar fiatalság hitvallása Ady Endre költészetének történelmi tanulsagai mellett ['I live in young hearts: The profession of faith of the Magyar youth in the historical lessons of Endre Ady's poetry']. Budapest: Hid.

Németh Andor. 1990 [1937]. "A magyar irodalom és Európa" ['Hungarian literature and Europe']. In Mi a magyar most? Tanulmányok a magyar jelen legfontosabb kérdéseiröl ['What is the Hungarian today? Essays on the most important issues of the Hungarian present']. Ed. Ferenc Fejtö. Budapest: Cserépfalvi - Gondolat - Tevan. 76-82.

Németh Gyula. 1931. "A magyar turánizmus" ['Hungarian Turanianism']. Magyar Szemle ['Hungarian Review'] 11.2(42) (February): 132-39.

Németh László. 1939. "Ágak és gyökerek” ['Branches and roots']. Magyarország ['Hungary'] (23 December). Quoted in Gyula Juhász. 1983. Uralkodó eszmék Magyarországon 19391944 ['Ruling ideas in Hungary, 1939-1944']. Budapest: Kossuth: 84.

. 1942. "Kisebbségben" ['In the minority']. Kisebbségben. Budapest: Magyar Élet, 2 vols. I: $11-93$.

. 1989 [1935]. “Magyarság és Európa” ['Magyardom and Europe']. In Sorskérdések ['Fate-questions']. Ed. Ferenc Grezsa. Budapest: Magvető és Szépirodalmi Könyvkiadó: 252-336.

. 1993 [1943]. "Németh László elöadása” ['László Németh’s speech']. Szárszó. Az 1943. évi balatonszárszói Magyar Élet-tábor elöadás- és megbeszéléssorozata ['Szárszó: The speeches and discussions from the 1943 Hungarian Life camp at Balatonszárszó']. Budapest: Püski. 39-52.

1989 [1940]. "Szekfü Gyula” ['Gyula Szekfü']. In Sorskérdések ['Fate-questions']. Ed. Ferenc Grezsa Budapest: Magvető és Szépirodalmi Könyvkiadó. 515-97.

Okolicsányi László. 1942. "Japán ápolja a turánizmus gondolatát. Mezey István nyilatkozata" ['Japan is cultivating the Turanian idea: István Mezey's statement']. Szabadság ['Freedom'] 4.8 (20 February).

Pálóczi Horváth Lajos. 1940. "Az igazi magyar fajvédelem” ['Real Magyar race-protection'] (pt. 1). Magyar Út ['Hungarian Way'] 9.28 (July): 3.

Pap Béla. 1937. "Kik vagyunk? ..." ['Who are we? . . ']. Magyar Út [Hungarian Way] 6.1 (1 January): 1.

Remenyik Zsigmond. 1937a. "Népek hazája, nagyvilág" ['Homeland of the people, the wide world!']. Szép Szó ['Beautiful Words'] 5.1(16) (July-August): 3-10.

. 1937b. "Vallomás és válasz" ['Declaration and response']. Szép Szó ['Beautiful Words']. 5.2(17) (September): 105-08.

Szabó Dezső. 1989 [1919]. Az elsodort falu ['The swept-away village']. Debrecen: A Debreceni Református Kollégium Gimnáziuma.

Szabó Zoltán. 1939. "Magyarság és Közép-Európa” ['Magyardom and Central Europe']. Kelet Népe ['People of the East'] 5.8 (August): 5-11. . 1941. "Turán és Eurázia" ['Turanianism and Eurasia']. Jelenkor ['The Current Era’] 
Esbenshade, Richard S. "Symbolic Geographies and the Politics of Hungarian Identity in the 'Populist-Urbanist

Debate,' 1925-44." Hungarian Cultural Studies. e-Journal of the American Hungarian Educators Association,

Volume 7 (2014): http://ahea.pitt.edu DOI: 10.5195/ahea.2014.174

3.18 (15 September), 11-12.

Széchenyi Ágnes. 2002. “Sznobok és parasztok” Válasz 1934-1938: Elvek, frontok, nemzedékek

[“'Snobs and peasants” Válasz 1934-1938: Ideas, fronts, generations']. Budapest:

Argumentum.

Szekfü Gyula. 1929. “A ‘turáni-szláv paraszt állam”" ['The "Turanian-Slavic peasant state”']. Magyar Szemle ['Hungarian Review']. V.1(17) (January): 30-37.

Todorova, Maria. 2005. "The Trap of Backwardness: Modernity, Temporality, and the Study of Eastern European Nationalism.” Slavic Review 64.1 (Spring): 140-64.

Trócsányi Zoltán. 1930. "A magyarság östörténete - Németh Gyula új könyve" ['The ancient history of Magyardom - Gyula Németh's new book']. Magyar Szemle ['Hungarian Review'] 10.3(39) (November): 273-83.

Udvardy Miklós. 1929. “Turáni átok” ['Turanian curses']. Elöörs ['Vanguard'] 2.21 (25 May): 13-14.

-uk-. 1929. “Turánizmus és Eurázia" ['Turanianism and Eurasia']. Elöörs ['Vanguard'] 2.35 (31 August), 14-15.

Vargyas Lajos. 1943. "Hagyomány és kultura” ['Tradition and Culture’]. Magyar Csillag ['Hungarian Star']. 3.18 (15 September): 377-87.

Wallerstein, Immanuel. 1974. The Modern World-system: Capitalist Agriculture and the Origins of the European World-Economy in the Sixteenth Century. New York: Academic Press.

Winichakul, Thongchai. 1994. Siam Mapped: A History of the Geo-Body of a Nation. Honolulu: University of Hawaii Press.

Wolff, Larry. 1994. Inventing Eastern Europe: The Map of Civilization on the Mind of the Enlightenment. Stanford, Calif.: Stanford University Press.

Zeidler, Miklós. 2007. Ideas on Territorial Revision in Hungary, 1920-1945. Eds. Thomas J. and Helen D. Kornfeld. Boulder: Social Science Monographs.

Zsolt Béla. 1992 [1939]. "Hortobágy.” A végzetes toll ['The fatal pen']. Sel. and Ed. András Bozóki. Budapest: Századvég.

Zsolt Zsigmond. 1942. "Az egyke-kérdés Magyarországon. (Biologiai szükségesség-e a magyarság pusztulása?) ['The Egyke question in Hungary (Is the destruction of Magyardom biological necessity?)']. Sorsunk ['Our Fate'] (Pécs) 2.3 (April-May): 161-78. 